\title{
感性設計における顧客の潜在的な評価視点の抽出とその効果* （他者間での視点の相互評価と想定外視点の抽出）
}

\author{
柳 澤 秀 吉*1, 村上
}

\section{A Method to Extract Customer's Latent Viewpoints in Kansei Design and Its Effect (Mutual Evaluation of Extracted Perspectives)

\author{
Hideyoshi YANAGISAWA*3 and Tamotsu MURAKAMI
} \\ ${ }^{* 3}$ Department of Engineering Synthesis, The University of Tokyo, 7-3-1 Hongo, Bunkyo-ku, Tokyo, 113-8656 Japan}

To respond recent diversifying customer's needs of a product, one of the most important work is to figure out customer's evaluation criterion of a product. Furthermore, emotional needs such as styling and user-friendliness, which is difficult to quantify, have been important factors with multitude of products having similar performance. Truly effective evaluation criteria often hides in customer's subconscious level, which is not easy to extract with frequency based statistics of conscious interviews, which is commonly used. In this paper, we propose an experimental method to externalize latent customer's evaluation criteria for product design. In this method, first, conscious perspectives for evaluating a product are extracted with evaluation grid method. Next, the extracted evaluation perspectives are mutually reviewed among the subjects and find effective latent evaluation criteria. We carried out an experiment based on te proposed method with a shape of plastic bottle. With the experimental result, we show that there are more effective perspectives in the minority one than in the majority one and the effectiveness of unexpected perspectives extracted from another subject.

Key Words: Design, Design Engineering, Product Planning, Customer Needs, Latent Evaluation Perspective, Kansei

\section{1. はじめに}

現在，製品に対する顧客の要求は急速に多様化し ており, 画一的かつ平均的な製品の供給では要求への 対応が困難となってきている．また，スペックとして 定量的に記述される品質に加え，審美性や使いやすさ など，人間の感性や感覚に依存する設計品質への関心 が集まっている(1)。これにより，設計の上流過程にお いて, 多様かつ感性を含む要求を的確に把握する必要 性が高まっている.

設計プロセスの上流過程において顧客の要求を技 術要素に展開する方法として, 品質機能展開 （QFD）(2)などが用いられている，また，感性に基 づく要求を具体的な設計属性一と変換する方法として SD 法 (Semantic Differential 法) などの種々の感性工 学的手法 ${ }^{(3.4)}$ が研究, 開発されている。これらは, 主 に感覚的な言葉で表される感性品質と, 計量可能な設 計属性との対応関係を，官能評価等により定式化する。 これまでに，筆者らは感性の多様性を考慮した感性 定量化手法(5)，および，言葉によらない感性要求の具

* 原稿受付 2007 年 4 月 6 日.

*1 正員, 東京大学大学院工学系研究科( $\mathbf{W} 113-8656$ 東京都文 京区本郷 7-3-1)

*2 正員, 東京大学大学院工学系研究科.

E-mail : hide@mech.t.u-tokyo.ac.jp
体化方法を開発してきた(6.8).

一方，これらの手法が有効に機能する前提として, 顧客が重視する評価項目を適切に選定する必要がある。 感性設計においては, 顧客の要求する感性品質や，そ れと関係する設計属性を選定する必要がある. 評価項 目を顧客から抽出する方法として，顧客に対する種々 の面接法が用いられている(9.10). 面接者の恣意性を排 除する認知構造に即した質問法として，ラダリング(10) や, 評価グリッド法(9)などが開発され，一般に用いら れている.これらは, 評価サンプルの総合評価から, 情緒的なベネフィット，機能的なベネフィット，そし て属性レベルへと慗がる因果関倸（ラダー）を言葉に より抽出し, 顧客の製品評価における認知構造を抽出 する方法である. 上位概念の抽出（ラダーアップ）と 下位概念の抽出（ラダーダウン）を段階的に聞くこと により方法により，質問者の恣意性を抑制している. 通常は，これらの面接法によって抽出された顧客の声 を集計し，頻度の高い項目を顧客が重視する評価の視 点として採用寸る場合が多、(11).

ところが，多数の顧客が意識的に回答した顕在的 な評価項目の満足化のみでは, 妥当ではあるが特徴の 薄い製品となる可能性が高い. 平均的な要求への過度 な追求による製品の画一化はその一例である. 
そこで, 本研究では, 頻度によらない潜在的な顧 客の評価の視点を抽出し，その有効性を実験により検 証する. すなわち, 面接法により複数の被験者から抽 出される多様な評価の視点を, 他者間で相互に再評価 させることにより，想定外の評価の視点を抽出する方 法を提案する. そして, 抽出された評価の視点の有効 性を実験により確認する.

感性品質が重視される製品の形態 (形, 材質, 色 など）を対象に実験を行い，他者の異質な評価の視点 が，自身の評価に与える影響を確認する，また，頻度 の低い顧客要求 (小さい顧客の声) と, 頻度の高い要 求 (大きい顧客の声) の, 各被験者における総合評価 への影響度合いを比較する，そして，個人が想定する 視点と, 想定外の他者の視点を比較し, 想定外の視点 が評価に与える影響を分析する。

\section{2.評価視点の相互評価による潜在視点の抽出 および評価法}

$2 \cdot 1$ 手法の概要 提案する手法の流れを以下に 示す.まず, 複数の評価サンプルを, 複数の被験者に 提示し総合評価を回答させる. そして, ラダリングに よって, 総合評価の理由を評価視点として抽出する. 評価視点は, $2 \cdot 3$ で説明する視点の構造にもとづい た質問形式による面接法により抽出する.

次に, 抽出した評価視点を単位視点に分割する. 得 られた単位視点の重複を排除し相互評価する視点, 再 評価視点とする.

そして, 同一の被験者に対して, 得られた再評価視 点の全てを相互に再評価させる. 評価項目は, 視点に 対する同意の度合い，総合評価への影響度合い，およ び意外感の度合いである，相互評価の実験は，記憶の 影響を排除するため, ラダリングによる視点の抽出実 験から時間をあけて実施する.

自己がラダリングで回答した視点と, 相互評価した 他者の視点との類似度, および想定度を算出する. そ して, 想定度と, 相互評価実験の評価から潜在的かつ 有効な評価視点を抽出する，以下，手法の詳細につい て述べる.

$2 \cdot 2$ 評価視点の抽出 複数の評価サンプルを用 意し, 被験者による総合評価, および評価の視点を抽 出する. 以下に手順を示す.

（1）評価サンプルの総合評価と分類配置：机の上 に, 評価サンプルを一列にならべ被験者に提示する. 次に, 被験者に, 評価サンプルの形態に対する総合評 価について, 最も評価の高いものと低いものを選ばせ,
それぞれ机上の左端と右端に配置する. その後, 残り の評価サンプルを，とても良い，やや良い，良くも悪 くもない, やや悪い, とても悪い, の5 段階で分類し, それぞれ机上に配置する.

(2) 評価グリッド法による評価視点の抽出：最も 良いと回答した評価サンプルから順に，その評価の理 由を, 評価グリッド法に基づく面接法により質問する.

評価グリッド法では，まず，他の総合評価のサンプ ルと比較して，なぜそれが良いか（あるいは悪いか） を聞く，そして，評価の上位概念を抽出するラダーア ップと, 下位の概念を抽出するラダーダウンと組み合 わせて逐次質問し，評価の因果関係を構造化する.

ラダーダウンでは，述べられた評価や理由について 「なぜその形状が良いと思うのか」，「そうなるため には，何がどうなることが必要か」と問い，徐々に具 体的な理由を引き出す, 一方, ラダーアップは, 述べ られた理由がどのような評価に繋がるのかを質問する. 例えば，「把持部に括れがあると，なぜよい形状と思 うか?」などを問う. ラダリングでの各質問は，2・ 3 で説明する視点の構造にもとづいておこなう。

$2 \cdot 3$ 視点の構造 本手法では, 評価グリッド法 の質問方法に図 1 に示寸視点の構造を導入し, 質問の 統制を図る. 視点は, 複数の理由から構成されている と考えられる. ここで, 視点とは, ラダリングによっ て回答される, 総合評価に対する一つの理由, すなわ ち一つのラダーを意味する. 本研究では, 図 1 に示す ように，各視点を，(1)ポジティブ（あるいは，ネガテ イブ）な視点か，(2)どのような観点にもとづく視点か， (3)どの部位に注目しているか, (4)その部位のどの設計 変数に対する視点か, (5)その設計変数はどのような変 数の值をとるかの, 五項目で構成されているとし, 各 項目について被験者に問う.

ここで観点とは，たとえば，「デザイン性の観点」 や「機能性の観点」のように，どのような見方からの 評価であるかを意味する，ここでは，評価サンプルの デザインの審美性やイメージに関する「感性の観点」, および飲みやすさや持ちやすさなど, 形態の機能的側 面の評価を「機能性の観点」として分類した。 また, これら以外の観点は, その種類を入力して追加した.

(3のどの部位に注目しているかは, 把持部, 底部など のように，対象を構成する部位である. 本研究では, こ れを，注目部位と呼ぶ．特定の部位でなく，全体を対象 にした視点の場合は，注目部位を「全体」とする. (4)は 注目部位のどの設計変数に対する視点かであり，形，表 面のパターン, 色, 材質などである. (5)の変数の值は, 注目する部位の設計変数がどのような值をとるかの值で 
ある. たとえば，本研究で用いるペットボトルの形態が 評価対象である場合，「把持部のくぼみが大きいととい う回答が得られたとする。この場合，「把持部」が注目 部位,「くぼみ」が設計変数,「大きいかが変数の值と なる。

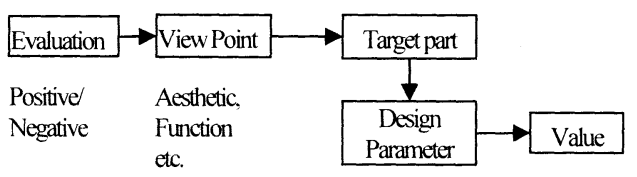

Fig. 1 Structure of evaluation perspective

$2 \cdot 4$ 抽出した評価視点の分割 ラダリングで得ら れた各被験者の視点全体を, 総合評価に対する要因ご とに分割する，視点全体を分割する単位は，図2に示 すように, 各評価サンプルの総合評価と直接的に因果 関係がある最上位の視点と, それらの理由となる下位 概念の視点の集合とする.

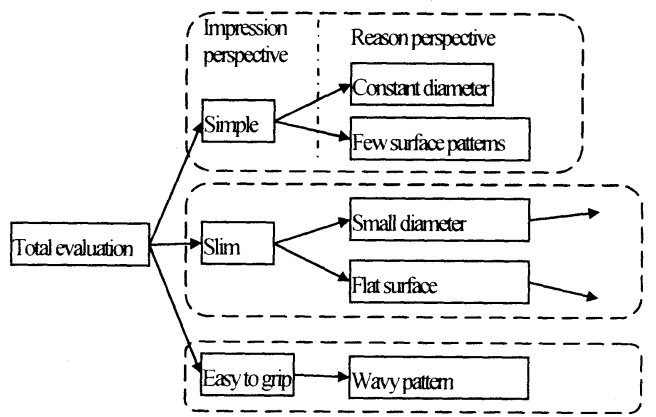

Fig. 2 Example of minimum unit of perspective

評価グリッド法により得られる視点の因果関係のリ ンクは，視点をノードとする有向グラフとみなせる （各ノードは，図1の構造をそれぞれ持つ）。そこで， 接続行列から, 階層構造化モデル (Interpretive Structural Modeling: ISM） ${ }^{(2)}$ 用い，最上位のノードを 導く. そして, 最上位のノードの可達行列を計算する ことで，最上位のノードと関係する視点を抽出する.

以下，分割したそれぞれの視点を単位視点と呼ぶ.

単位視点の構造は, 主観的な印象とその理由を説明 する説明の二項よりなる. 例えば, 抽出された視点が 「シンプルだー径が一定かつ表面のパターンが少ない から」の場合，「シンプルだ」が师象であり，「径が 一定かつ表面のパターンが少ないから」は, その理由 である．前者の認識は，個人の感性や感覚に依存し，
後者は依存しない．このように，同じ視点であっても， その性質が異なるため, 本研究ではこれらを分けて扱 い, それぞれ，印象視点と理由視点と呼ぶことにする. 抽出した単位視点を集計し, 意味の重複する視点を 省いて, 再評価視点とする.

$2 \cdot 5$ 抽出した視点の相互評価 抽出した再評価視 点のすべてを, 対応する評価サンプルと共に, 一つず つ, 被験者に提示し再評価させる. 自身が回答した評 価視点（以下，自視点）も，比較のため同様に評価さ せる.

評価する項目は，視点に対する同意の度合い，提示 された視点に対してどれだけ意外性を感じるかの度合 い，および提示された視点が総合評価にどれだけ影響 しうるかの度合いである。

・視点に対する意外感の度合い 提示される再評価 視点の意外感について, (1)その視点には気付いていた, (2)想定外だが意外性を感じない，(3)想定外でやや意外 性を感じる，(4)想定外でとても意外な視点だ，(5)想定 外で非常に意外な視点だ，の 5 段階で，印象視点，お よひ理由視点のそれぞれについて回答させる.

・視点に対する同意の度合い提示される再評価視 点に対する同意の度合いとして，(1)同意できる，(2)部 分的に同意できる，(3)全く同意できない，の3段階で 回答させる．部分的に同意できない回答の場合は，印 象視点か理由視点かを選択させる.

・総合評価への影響度合い再評価視点が, 被験 者の総合評価にどの程度影響するか,つまり被験者に とっての再評価視点の重要度を回答させる．評価は，

「ポジティブにとても影響する」から，「ネガティブ にとても影響する」までの 7 段階である.

\section{$2 \cdot 6$ 単位視点間の類似度と想定度 相互評価}

で得られた意外感の度合いは，再評価視点が提示され た後の回答である，そのため，(1)「その視点を想定し ていた」との回答であっても，その真偽は定かではな い. 実際，コロンブスの卵のように，結果が示された 後でその結果を想定していたと思い込む後知恵バイア ス (Hindsight bias) が, 実験により確認されている (13). したがって, ここでの意外感の度合いは, 再評価 視点の主観的な印象としての意外感を表す結果とみな す.

一方, 本研究では, 自己の想定内の視点と, 他者の 想定外の視点の比較をしたい. そこで, 自視点と, 他 者の再評価視点の類似の度合いを類似度として定量化 する. 他者の視点をどれだけ事前に想定していたかを 検討するため, 他者の視点に自身の視点が含まれる割 合を，自身の視点に対する他者の視点の類似度として 
算出する. 今, $i$ 番目の単位視点 $P_{i}$ とし, $P_{i}$ に含まれ

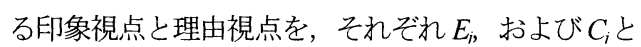
する.このとき, 単位視点 $P_{i}$ からみた, 他者の単位 視点 $P_{j}$ の印象視点に関する視点間類似度 $D_{e}\left(E_{i}, E_{j}\right)$ を, 以下の式より求める.

$$
D_{e}\left(E_{i}, E_{j}\right)=\frac{\left|E_{i} \cap E_{j}\right|}{\left|E_{j}\right|} \cdots \cdots \cdots
$$

同様に, 単位視点 $P_{i}$ からみた, 単位視点 $P_{j}$ の理由 視点に関する視点間類似度 $D_{c}\left(C_{i}, C_{j}\right)$ を, 以下の式よ り求める.

$$
D_{c}\left(C_{i}, C_{j}\right)=\frac{\left|C_{i} \cap C_{j}\right|}{\left|C_{j}\right|} \cdots \ldots
$$

ただし， $|X|$ は，集合 $X$ の要素の数である.

次に, 被験者 $p$ の $i$ 番目の単位視点に含まれる印象 視点之理由視点を，それぞれ $E_{p i}$ および $C_{p}$ とする. このとき, 被験者 $p$ にっての, 被験者 $q$ の $j$ 番目の 印象視点 $E_{q}$ に対寸る想定の度合い $S_{e}\left(E_{q} \mid p\right)$ を, 式(3)に より求める.

$$
S_{e}\left(E_{q i} \mid p\right)=\max _{i}\left(D_{e}\left(E_{p i}, E_{q i}\right)\right) \cdots \cdots
$$

同样に, 被験者 $p$ にっての, 被験者 $q$ の $j$ 番目の 理由視点 $C_{q j}$ に対する想定の度合い $S_{c}\left(C_{q j} \mid p\right)$ は,

$$
S_{c}\left(C_{q j} \mid p\right)=\max _{i}\left(D_{c}\left(C_{p i}, C_{q i}\right)\right) \cdots \cdots(4)
$$

となる. 以下, $S_{e}$ と $S_{c}$ を, それぞれ印象視点の想定 度, およひ理由視点の想定度と呼ぶ. そして, 単位 視点の想定度 $\mathrm{S}$ を, 以下により求める.

$$
S=\frac{S_{e}+S_{c}}{2} \cdots \ldots \ldots \ldots
$$

なお，自身が他者の視点をどれだけ想定していたかの 度合いは, 他者の視点と一致する要素の最も多い自身の 視点の類似度によって説明できるため，想定度を視点間 類似度の最大值とした。

\section{3.ケーススタディ実験}

$3 \cdot 1$ 実験の目的 本実験では，意匠性や使いや すさが問題となるペットボトルの形態を評価対象とし, 提案手法にもとづき想定外の評価視点を抽出し, その 有効性を以下の 2 点により確認する.

(1) 評価対象への総合評価に寄与する度合いについて, 他者の想定外の評価視点と想定内の視点とを比較する。 (2) 他者間で共有寸る頻度の高い評価視点之, 多数の 被験者が想定しない少数の評価視点とを比較する. 総 合評価に対する寄与の度合いの最大值が, 共通する評
価視点よりも, 想定外の評価視点の方が高い場合, 少 数の視点は無視できない. したがって, この場合, 本 手法によって少数の視点の中に潜在する有効な視点を 抽出する必要性と有効性が示される.

$3 \cdot 2$ 評価サンプル 本実験では, 飲料用ペット ボトルの形態を評価対象とする. ペットボトルは, 付 加価値を高めるため, 現在, 意匠性や使いやすさの観 点から形態が多様化している. 特に, 内容物が水やお 茶などのように差別化が難しい製品では，パッケージ による差別化が重要となる.

ここでは, 現在販売されている $500 \mathrm{ml}$ のペットボト ルから, 図3に示寸 10 種類の多様な形状を選定し, 実験における評価対象とした。メーカの印象や内容物 の嗜好などの影響を排除し, ラベルを除去し, 中に水 を入れた。
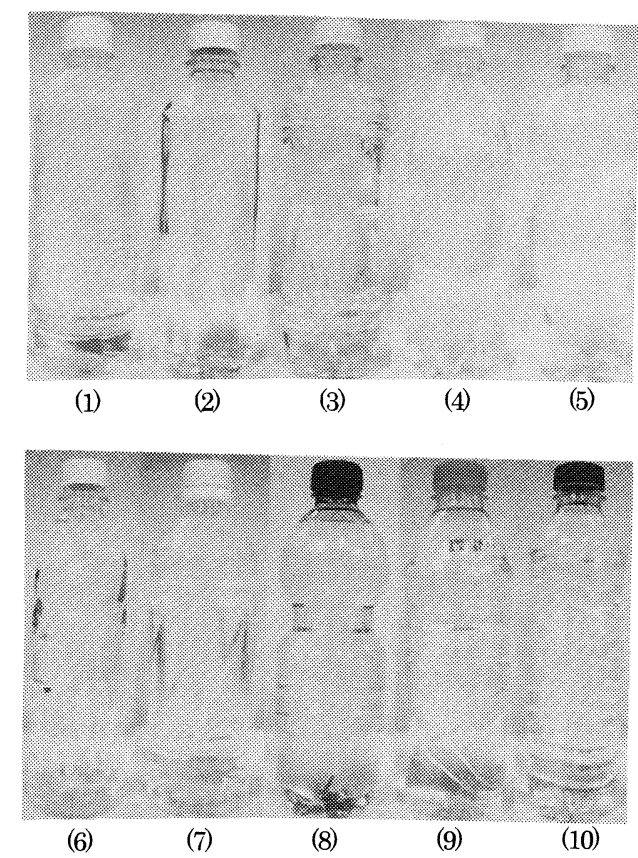

Fig. 3 Plastic bottles used in the evaluation experiment as design samples

$3 \cdot 3$ 実験の方法およひ実験システム 提案手法 にもとづき, $3 \cdot 2$ で示した 10 個のペットボトルの形 態を評価対象として実験を実施する．被験者は，20 代の男子 9 名である. 実験は, 実験 1 として面接法に よる評価視点の抽出, 実験 2 として再評価視点の相互 評価実験の 2 回に分けて実施する．なお，記憶による 影響を排除するため, 実験 1 と実験 2 は, 一週間あけ て実施する。 


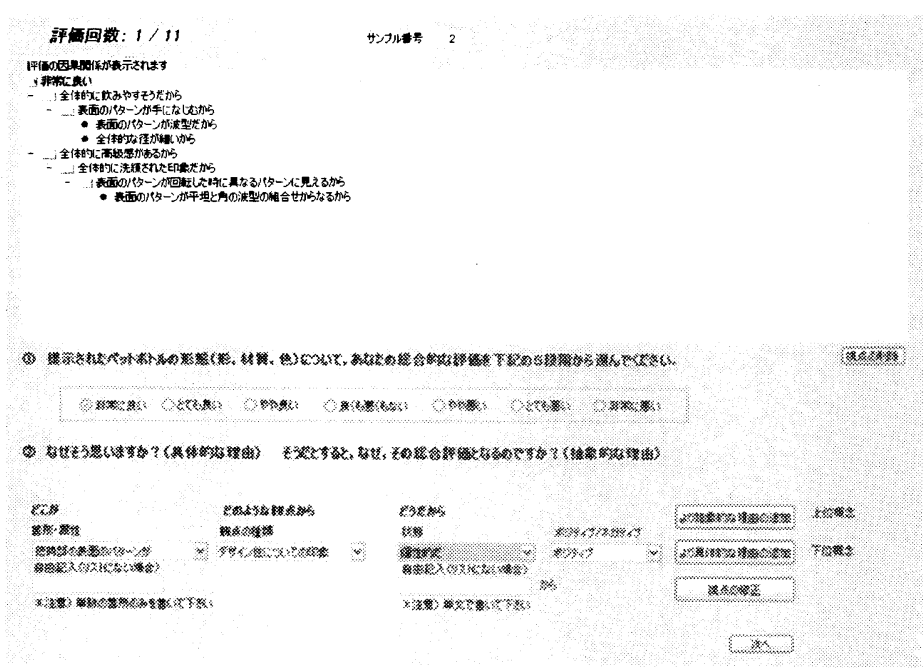

Fig. 4 An evaluation grid method based interview support system applying the structure of evaluation perspective

実験 1 は, 図 4 に示寸視点の構造に沿ったインタフ エースを有する回答集計システムを作成し，これを用 いて行った. 本システムでは, 視点の構造の各項目で ある, ポジティブノネガティブ, 観点, 注目部位, 設 計変数および変数の值をそれぞれ入力する. 本システ ムにより，これまで集計が困難な自由記述による回答 を, 視点の構造と視点間の因果関係により系統的に集 計可能である.

想定される視点の項目を験者が事前に入力し, 実験 の際その中に該当する項目があれば選択する. また, 該当する項目がない場合は新規に入力する. 入力され た項目は自動的に保存され, 再度同様の回答の際に選 択できる.この機能により, 同一の異なる表現での重 複する項目の入力を避ける.

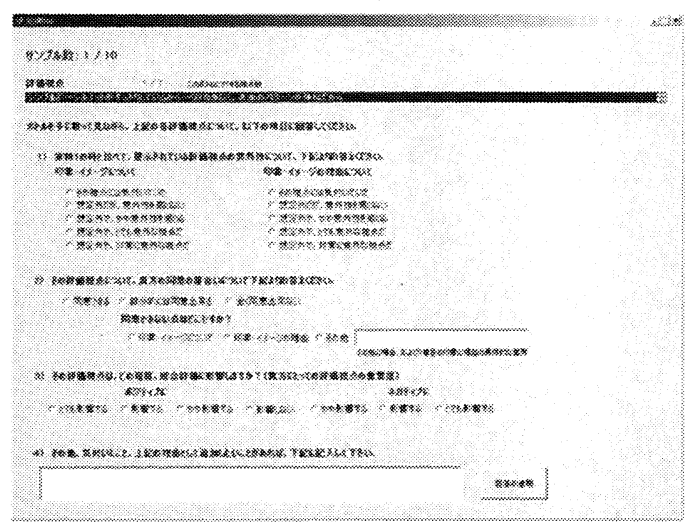

Fig. 5 A questionnaire system used for evaluating perspectives extracted at experiment 2
各視点の閒の関係は，図4に示すように木構造状に 表示されるため, 験者は, これを確認し質問の漏れを 防止することが出来る.

実験 2 は，記憶による影響を抑えるため，実験 1 か ら一週間後に実施した．本実験では，ペットボトルの 形状についての評価を向上させている要因を探るため, ポジティブと判断された視点を再評価視点として抽出し た. 評価実験は，図5に示す回答のインタフェースを 作成しこれを用いて行った.

\section{4. 実験結果と考察}

4-1 想定外視点と想定内視点の比較 実験 1 で は, 97 個の再評価視点が抽出された. 実験 2 で得ら れた，再評価視点に対する意外感の度合いの結果にお いて，実験 1 で回答した自己の視点とは異なる想定外 とみなされる他者の視点に対して意外感の度合いが 1 , すなわち「その視点には気付いていた」との回答が多 数確認された.

たとえば，実験 1 における被験者 3 の評価サンプル 2 に対する視点として，「新鮮そうだークリアなイメ ージだからー平面的だから」，および「普段使いやす いいシンプルだからい表面のパターンがなく平面的だ から」を得ている.これらは, デザイン性の観点から のみの視点である。一方，実験 2 において，他者の視 点である「飲みやすそうだーどこでも持てるから一径 が太くも無く細くも無く, シルエットが平坦だから」，

「飲みや寸そうだー径が細く，〈びれがないから」， および「飲みやすそうだー表面のパターンが手になじ むから一径が細く，表面のパターンが波型だから」な 
どの，機能性の観点からの視点について，意外感の度 合いが 1，かつ総合評価への影響度合いが 3 の「ポジ ティブにとても影響する」と回答している.

このことから，意外感の度合いは実験 2 の時点にお ける被験者の意外感の主観的な印象であり，実験 1 の 時点において実際に想定していたかどうかの指標とし ては適切でないことがわかる.

そこで, $2 \cdot 6$ で述べた想定度を計算し，再評価視 点を, 実験 1 の時点で自身が想定していた視点と, 想 定していなかった想定外の視点に分ける.ここで，想 定度 $S=1$ となる再評価視点を, 完全想定内視点

(Expected perspective)， $S=0$ となる再評価視点 を想定外視点(Unexpected perspective), および, 想 定度が $0<S<1$ の視点を部分想定視点(Partially

Expected perspective)とする. なお，完全想定内視 点には被験者自身の視点も含まれる.

従来手法における，被験者間で共通する頻度の高い 評価項目を重視するアプローチでは，完全想定内視点 が総合評価に対する影響が高いとする暗黙の仮定に基 づいている. しかし，実験 2 での再評価の結果では， 完全想定内視点の総合評価一の影響度合いが想定外視 点のそれよりも低い例も見られた。つまり，回答した 自身の視点の総合評価に対する影響度合いが低い場合 が確認された.

図 5 に, 被験者ごとの, 完全想定内視点における総 合評価への影響度合いの平均值, および 95 パーセン 卜信頼区間を示す。ここでは，影響の大きさを調べる ため, -3 から 3 までの回答結果の絶対值を用いている

図5において, 信頼区間の最大值に注目すると, 総

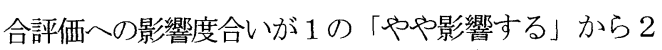
の「影響する」の間の被験者が三人, 2 から 3 「とて も影響する」の間が四人, 総合評価への影響度合いが 3 に達寸る被験者は一人である.

このことから，自視点を含む想定内の評価視点を， 時間をおいて再評価した場合, 必ずしも総合評価に対 する影響度合いが高いとはいえないことがわかる。

一方，想定外の視点において，総合評価への影響度 合いが高い視点が確認された，そこで，想定外の視点 の中に影響の大きい視点が，どの程度存在するかを調 べる. 図6に, 各被験者において, 総合評価への影響 度合いが高い想定内視点, 想定外視点, およひ部分想定 視点の数を示す.ここでは, 影響度が想定内視点の信頼 区間の最大值以上となる視点を影響度が高い，として数 えた.

被験者間で共通した傾向として, 視点の数の大小関係 が，完全想定内視点＜部分想定視点＜想定外視点，とな
っている. したがって，想定外の視点には，想定内の視 点よりも多く総合評価への影響度合いが高い視点が存在 する.

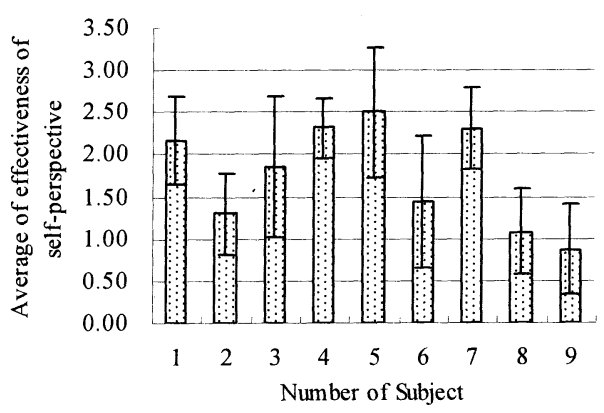

Fig. 5 Average effectiveness of self -perspectives

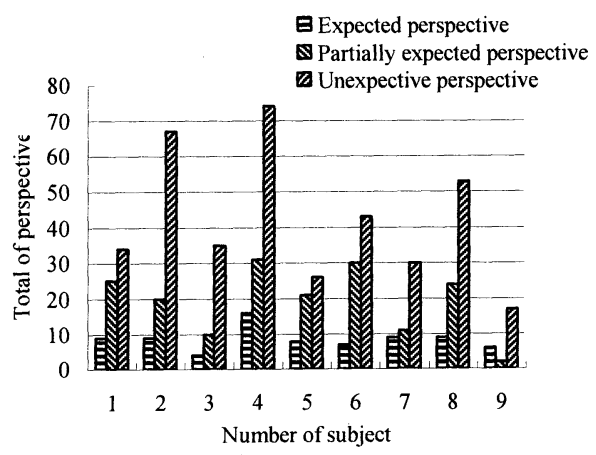

Fig. 6 A total of perspectives whose effectiveness is more than max value of confidential interval of effectiveness of expected perspective

以上の結果から，面接法によって意識的に回答され た想定内の評価視点だけでは, 顧客の評価視点の抽出 には十分でない，つまり，自身の想定内視点の再評価 の結果から, 必ずしも回答した想定内視点が自己の総 合評価に最大限に影響するとは限らない，そして，他 者が意識化した想定外の評価視点を相互に再評価させ ることにより，想定外の他者の視点から，自身の視点 よりも多くの有効な評価視点を抽出可能である.

\section{$4 \cdot 2$ 再評価視点の共通想定度と総合評価への影響} 度合いの関係 従来手法では, 面接法などで被験者 から抽出した多数の評価項目の中で, 共通する回答を 抽出し, 顧客の重要視する評価尺度とする例が多い(12). しかし，前節の結果により自身が回答した想定内の視 点が, 想定外の視点と比べて有効であるとは限らない. そこで, 各被験者における再評価視点の共通性の度 合い (以下, 共通想定度と呼ぶ) と, 総合評価に対す る影響度合いとの関係を分析する。 
今, 被験者 $q$ が回答した再評価視点 $P_{q}$ の共通想定 度を, 印象視点 $E_{q}$ ，および理由視点 $C_{q}$ のそれぞれに ついて以下のように求める.

$$
\begin{aligned}
& \sum_{p} S_{e}\left(E_{q} \mid p\right) /(n-1), \quad p \neq q \cdots \cdots \cdots(6) \\
& \sum_{p} S_{c}\left(C_{q} \mid p\right) /(n-1), \quad p \neq q \cdots \cdots \cdots(7)
\end{aligned}
$$

ただし, $n$ は被験者数である. この值が 1 に近いほ ど, 被験者間で共通して想定されていた共通性の高い 視点である. 共通想定度が 0 であれば, 被験者 $q$ のみ が気付いていた視点といえる.

図 7 に, 再評価視点の印象視点における総合評価一 の影響度合いの平均值と共通想定度を示す，共通想定 度が高くなるに従い，1から 1.5 付近に総合評価への 影響度合いが漸近している。一方，共通想定度が低い 視点では, 総合評価への影響度合いが 0.5 から 2.5 まで 幅広く分布している.

図8は，再評価視点の理由視点における総合評価一 の影響度合いの平均值と, 共通想定度を示している. 印象視点の場合と比べてややバラツキが大きいが，同 椂に漸近の傾向がある. また, 共通想定度が高い領域 における総合評価への影響度合いの平均値は, 同様に 最大值を示していない.

共通的に多くの被験者が想定している視点において は総合評価への影響度合いは安定しているが，「やや 影響する」から「影響する」程度の妥当な視点である. 一方, 共通的に想定外の視点には, 共通して想定して いる視点よりも総合評価への影響度合いの高い視点が 含まれていることがわかる.すなわち，面接法の回答 による共通性の高い評価視点よりも, 少数の想定外の 評価視点から, より有効な視点が抽出可能であるとい える.

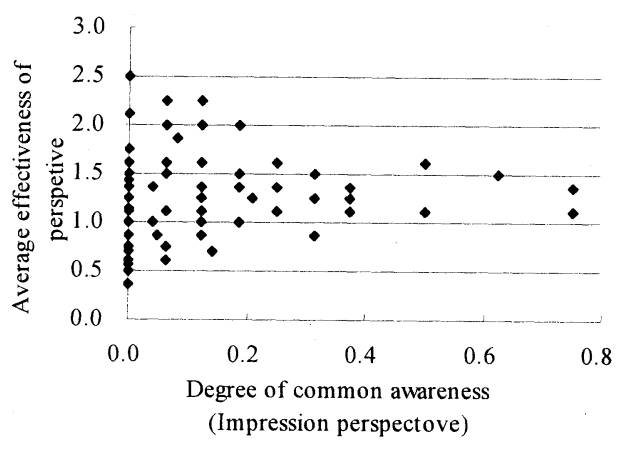

Fig. 7 Relation of common awareness of impression perspective to perspective's effectiveness

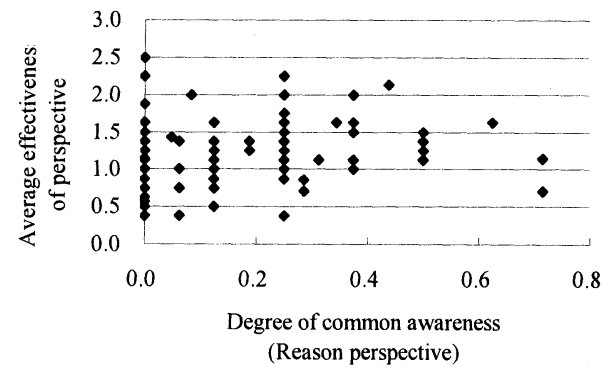

Fig. 8 Relation of common awareness of reason perspective to perspective's effectiveness

共通想定度の低い領域においては, 総合評価への影 響度合いが高い視点と低い視点が混在していた．そこ で，両者の違いを分析する. 図 9 に, 意外感の度合い の平均值と総合評価への影響度合いの関係を示す. 意 外感の度合いと総合評価への影響度合いには負の相関 関係がみられる. 特に, 総合評価への影響度合いが高 い2 以上の視点では, 多くの被験者が意外性を感じて いないことが分かる.

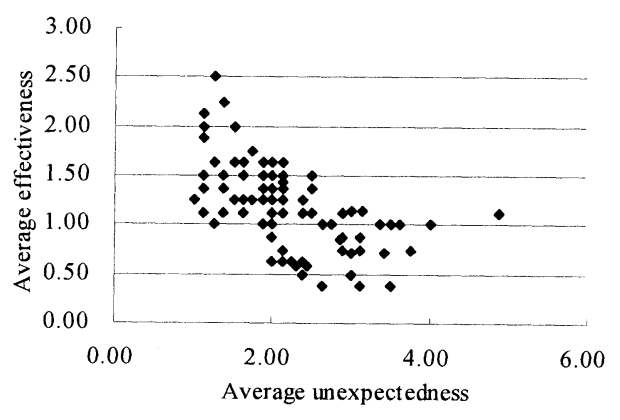

Fig. 9 Relationship of average unexpectedness to average effectiveness or perspectives evaluated in experiment 2

図 10 に, 意外感の度合いの平均值と共通想定度の 関係を示す. 図 10 から，共通想定度が低い場合でも， 意外性が大きく高低に分布していることがわかる。つ まり，共通想定度が低い視点でも，意外性を感じない 視点が存在する. そして, それらの視点が, 多くの被 験者の総合評価に高い影響を与えていることが分かる。 したがって，想定外の視点であるにもかかわらず，意 外性を感じていない視点が, 総合評価への影響度合い の高い視点であるといえる. 


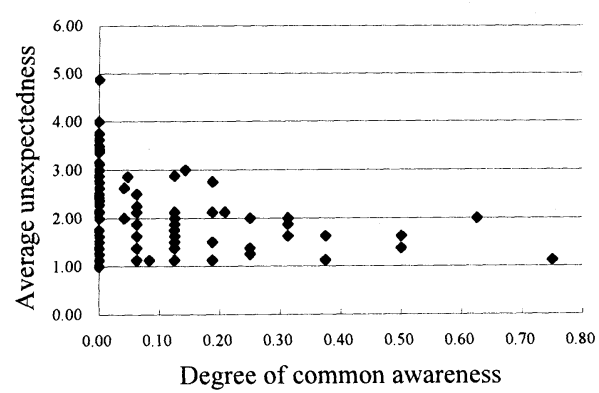

Fig. 10 Relationship of common awareness to unexpectedness for perspectives evaluated in experiment 2

\section{5.おわりに}

感性設計においては，設計の上流で，対象となる製品 について, 顧客が重視する評価視点の把握が重要である. これまでの，面接法により抽出される頻度の高い評価視 点を採用するアプローチに対し，本研究では，想定外の 評価視点に，潜在的で有効な視点が潜在すると考え，実 験により検証を行った. 面接法によって抽出される多様 な評価視点を，被験者間で相互に再評価する方法により， 想定外の潜在的な評価視点を抽出し, 抽出した視点の評 価を行った. ペットボトルの形態の感性品質を対象とし て実験を行った結果, 以下の知見を得た.

- 面接法で，被験者から得られる意識的な視点，およ ひ想定内の評価視点は，妥当であるが対象の総合評 価に最大限に影響しない。

・本研究で提案した，面接法で被験者から得られる回 答を相互に再評価する方法により, 想定内の視点よ りも，想定外の評価視点において，対象の総合評価 に寄与する視点を多数抽出可能であることが確認さ れた.

・被験者間で共通して想定している評価視点よりも, 被験者間で共通して想定していないり少数の評価視点 において, より総合評価に対する影響が大きい視点 が存在する。

・共通想定度が低い視点において，意外性を感じてい ない視点が, 総合評価への影響度合いが高い視点で ある.

以上より, 顧客からの評価視点の抽出において, 頻度 の高い顕在的な回答よりも, 頻度が低く想定外の潜在的 な視点を抽出することの必要性が明らかになった. そし て, 被験者間での視点の相互評価による力法が, 潜在的 な視点を抽出に有効であることを示した.
なお，本研究の一部は，文部科学省科学研究補助金 (№. 17760115)，およひ財団法人みずほ学術振興財団工 学研究助成金の助成により実施した.

\section{文献}

(1) Yanagisawa, H, Human Centered Design Handbook (in Japanese), (Fukuda, S. edt), (2006), pp. 32-56, Maruzen.

(2) Akao, Y., QFD : Past, Present and Future, Proceedings of Int1 Sympasium on QFD'97,(1997).

(3) Mori, N., Kansei Engineering for Designing, Journal of Japan Saciety for Fuzzy Theory and Systems, Vol.11, No.1 (1999), pp.5263.

(4) Yagawa, M., et al, ,Kansei and Design,(in Japanese) (1999), Baifukan

(5) Yanagisawa, H. et al, Development of Industrial Design Support System Using Impression Words, Transactions of the Japan Saciety of Mechanical Engineers, Series C, Vol.67, No.657 (2001), pp.1682-1688.

(6) Yanagisawa, H., Fukuda, S., Development of Interactive Industrial Design support System Considering Customer's Evaluation, JMSE International Journal, Series C, Vol. 47, No. 2 (2004), pp. $762-769$.

(7) Yanagisawa, H., Fukuda, S., Interactive Reduct Evolutionary Computation for Aesthetic Design, Transactions of the AMSE, Journal of Computing and Information Science in Engineering, Vol.5, No.1(2005), pp. 1-7.

(8) Yanagisawa, H. and Fukuda, S., Global Feature Based IREC, Transactions of the Japan Society of Mechanical Engineers, Series C, Vol. 70, No. 699(2004), pp.322-330.

(9) Sanui, J., Visualization of users' requirements: Introduction of the Evaluation Grid Method. in Proceedings of the 3rd Design \& Decision Support Systems in Architecture \& Urban Planning Conference, Vol.1, (1996), pp.365-374.

(10) Gutman, J., A Meansend Chain Model Based on Consumer Categorization Process, Journal of Marketing, 46, (1982), pp.60-72.

(11) Motomura, Y., Kanade, T., Quantitative Modeling for Personal Construct and Probabilistic Reasoning, Technical Report of IEICE, NC2004-119, (2005), pp.25-30.

(12) Malone, D.W., An Introduction to the Application of Interpretive Structural Modeling, Proceedings of the IEEE, Vol.63, №.3(1975), pp. 397- 404

(13) Hertwig, R.et al,"Hindsight bias: How knowledge and heuristics affect our reconstruction of the past", Psychology Press, Vol11 No.4-5(2003), pp.357-377. 